ISSN: 2302-8556

E-Jurnal Akuntansi Universitas Udayana

Vol.24.3.September (2018):2274-2303

DOI: https://doi.org/10.24843/EJA.2018.v24.i03.p24

\title{
Pengaruh Corporate Social Responsibility Terhadap Nilai Perusahaan dengan Profitabilitas dan Free Cash Flow Sebagai Pemoderasi
}

\author{
I Made Adi Mahendra ${ }^{1}$ \\ Ni Gusti Putu Wirawati² \\ ${ }^{1}$ Fakultas Ekonomi dan Bisnis Universitas Udayana (Unud), Bali, Indonesia \\ email: adiminyo@gmail.com/08129652902 \\ ${ }^{2}$ Fakultas Ekonomi dan Bisnis Universitas Udayana (Unud), Bali, Indonesia
}

\begin{abstract}
ABSTRAK
Setiap perusahaan akan berusaha untuk meningkatkan nilai perusahaan melalui peningkatan kemakmuran pemilik atau para pemegang saham dengan cara meningkatkan kinerja perusahaan. Peningkatan kinerja perusahaan salah satunya dapat dilakukan dengan cara menerapkan tanggung jawab sosial (CSR). Penelitian ini bertujuan untuk menguji dan mendapatkan bukti empiris pengaruh Corporate Social Responsibility (CSR)terhadap nilai perusahaan dengan profitabilitas dan free cash flow sebagai pemoderasi. Penelitian ini dilakukan pada perusahaan pertambangan yang terdaftar di Bursa Efek Indonesia (BEI) tahun 2013-2016. Metode penentuan sampel yang digunakan adalah purposive sampling. Jumlah sampel yang memenuhi kriteria adalah 10 perusahaan. Metode pengumpulan data dilakukan dengan metode dokumentasi. Teknik analisis data yang digunakan adalah Moderated Regression Analysis (MRA). Penelitian ini berhasil menunjukkan Corporate Social Responsibility berpengaruh positif dan signifikan terhadap nilai perusahaan. Hasil pengujian moderasi antara Corporate Social Responsibility dengan nilai perusahaan menunjukkan pengaruh positif yang artinya profitabilitas dan free cash flow memperkuat pengaruh Corporate Social Responsibility terhadap nilai perusahaan.
\end{abstract}

Kata kunci:nilai perusahaan, CSR, profitabilitas, free cash flow

\begin{abstract}
Every company will strive to increase the value of the company through increasing the prosperity of the owner or shareholders by improving the company's performance. Increased corporate performance one of which can be done by applying social responsibility (CSR). This study aims to test and obtain empirical evidence of the influence of Corporate Social Responsibility (CSR) on the value of companies with profitability and free cash flow as a moderator. This research was conducted at mining company listed in Bursa Efek Indonesia (BEI) year 2013-2016. Sampling method used is purposive sampling. The number of samples meeting the criteria is 10 companies. Methods of data collection is done by documentation method. Data analysis technique used is Moderated Regression Analysis (MRA). The result of moderation testing between Corporate Social Responsibility and corporate value shows a positive influence which means profitability and free cash flow strengthens the influence of Corporate Social Responsibility towards firm value.

Keywords: firm value, CSR, profitability, free cash flow
\end{abstract}


I Made Adi Mahendra dan I Gusti Putu Wirawati. Pengaruh...

\section{PENDAHULUAN}

Perkembangan dunia bisnis saat ini menimbulkan persaingan antar perusahaan. Perusahaan yang mempertahankan eksistensinya dalam jangka panjang dituntut untuk mampu mengontrol potensi finansial maupun non finansial dalam meningkatkan nilai perusahaan. Memaksimalkan nilai perusahaan penting artinya bagi suatu perusahaan, karena tujuan utama perusahaan yang telah go public adalah meningkatkan kemakmuran pemilik atau para pemegang saham melalui peningkatan nilai perusahaan (Salvatore, 2005). Sebuah perusahaan yang baik harus mampu mengontrol potensi finansial maupun potensi non finansial di dalam meningkatkan nilai perusahaan untuk eksistensi perusahaan dalam jangka panjang. Menurut Brigham (2001) nilai perusahaan merupakan harga yang bersedia dibayar oleh calon pembeli apabila perusahaan tersebut dijual. Sedangkan menurut Keown (2004) nilai perusahaan merupakan nilai pasar atas surat berharga hutang dan ekuitas pemegang saham yang beredar. Nilai perusahaan merupakan persepsi investor terhadap tingkat keberhasilan perusahaan yang sering dikaitkan dengan harga saham dan profitabilitas.

Harga saham yang tinggi membuat nilai perusahaan juga tinggi. Nilai perusahaan yang tinggi akan membuat pasar percaya tidak hanya pada kinerja perusahaan saat ini, namun juga pada prospek perusahaan di masa depan. Nilai perusahaan dalam penelitian ini didefinisikan sebagai nilai pasar, seperti penelitian yang pernah dilakukan oleh Nurlela dan Islahuddin (2008) karena nilai pasar dapat memberikan kemakmuran pemegang saham secara maksimum apabila harga saham 
ISSN: 2302-8556

perusahaan meningkat. Semakin tinggi harga saham, maka makin tinggi pula kemakmuran pemegang saham.

Salah satu kasus pencemaran lingkungan yang mendapat kritikan secara internasional yaitu kasus PT. Freeport Indonesia. Menurut Basalamah \& Jermias (2005). PT. Freeport Indonesia telah mencemari lingkungan alam, lingkungan sosial, dan budaya disekitar area pertambangan di Papua Barat. Dimana kasus yang menimpa PT. Freeport Indonesia mendapat kritikan secara internasional sehingga menurunkan citra dari perusahaan tersebut. Menurunnya citra perusahaan ini berdampak juga terhadap menurunnya nilai perusahaan karena investor enggan untuk berinvestasi pada perusahaan tersebut.

Salah satu faktor yang dapat mempengaruhi nilai perusahaan, yaitu tanggung jawab sosial perusahaan (Corporate Social Responsibility). Corporate Social Responsibility (CSR) merupakan bentuk pemahaman perusahaan akan pentingnya tanggung jawab perusahaan dalam meminimalisir efek negatif yang timbul dari segala kebijakan dan akitfitas operasional perusahaan. Konsep CSR adalah konsep yang berfokus pada pemenuhan kesejahteraan triple bottom line dengan tidak hanya berorientasi pada profit bagi shareholder semata (single bottom line), akan tetapi juga berfokus dalam membangun hubungan sosial terhadap stakeholder dan kelestarian lingkungan alam sekitar yang diharapkan dapat mendukung peningkatan kinerja dan nilai perusahaan. Konsep CSR dijadikan indikator penting untuk menilai kemampuan perusahaan dalam mempertahankan eksistensi dan pertumbuhan bisnis secara berkelanjutan. 
I Made Adi Mahendra dan I Gusti Putu Wirawati. Pengaruh...

Peran CSR sangat penting terlebih bagi perusahaan yang menjalankan kegiatan usahanya di bidang dan atau berkaitan dengan sumber daya alam dikarenakan perusahaan wajib melaksanakan tanggub jawab sosial dan lingkungan sesuai dalam UU Perseroan Terbatas No. 40 tahun 2007 pasal 74 (www.bapepam.go.id). Keputusan Ketua Badan Pengawas Modal dan Lembaga Keuangan No. KEP134/BL/2006 mewajibkan perusahaan publik untuk menyampaikan laporan tahunannya yang berisi penjelasan terkait aktivitas dan cost yang digunakan dalam kegiatan tanggung jawab sosial dan lingkungan. Corporate Social Responsibility menjadi salah satu aspek yang dapat dipertimbangkan pengaruhya dalam memaksimalkan nilai perusahaan.

Pengungkapan CSR dapat meningkatkan nilai perusahaan sebab teori stakeholder menekankan bahwa perusahaan wajib mengungkapkan informasi kegiatan CSR sebagai bentuk rasa tanggung jawab perusahaan terhadap pihak stakeholder yang akan terkena dampak dari keberadaan perusahaan (Chairiri dan Ghozali, 2007). Pengungkapan CSR yang lebih luas dalam laporan tahunan merupakan sinyal positif yang diberikan perusahaan kepada stakeholder agar terjalin komunikasi yang baik diantara kedua pihak tersebut sehingga menimbulkan kepuasan dari stakeholder. Perusahaan yang dapat mempertahankan kepuasaan dari stakeholder, maka perusahaan tersebut akan memperoleh penerimaan terhadap keberadaan perusahaan di tengah-tengah masyarakat. Perusahaan juga mendapatkan dukungan dan persetujuan dari stakeholder terhadap kebijakan yang diambil dalam rangka meningkatkan nilai perusahaan. 
ISSN: 2302-8556

E-Jurnal Akuntansi Universitas Udayana Vol.24.3.September (2018):2274-2303

Indikator pengungkapan CSR dalam penelitian ini diukur dengan proksi Corporate Social Responsibility Disclousure Index (CSRDI) dimana mengacu pada pedoman standar pengungkapan CSR yang diakui secara internasional yaitu Global Reporting Initiative (GRI) G4. indikator pengungkapan ini dijabarkan dalam 91 item pengungkapan tanggung jawab sosial perusahaan. Semakin banyak item CSR yang diungkapkan maka semakin baik prospek kinerja perusahaan di masa mendatang dan semakin baik pula persepsi investor terhadap perusahaan yang tercermin dari meningkatnya harga saham dan nilai perusahaan.

Pengungkapan CSR secara signifikan berpengaruh positif terhadap nilai perusahaan, dimana hal tersebut sejalan dengan penelitian yang dilakukan oleh Nguyen et al. (2005), Fodio et al. (2013), Silvia (2012), Gherghina et al. (2014), Harjoto dan Jo (2011) serta Servaes dan Tamayo (2013) menjelaskan bahwa semakin luas pengungkapan CSR maka semakin tinggi nilai perusahaan. Hasil bertentangan ditunjukkan dalam penelitian Kurniasari dan Warastuti (2015), Mulyadi dan Yunita (2012), serta Tija dan Setiawati (2012) yang menemukan bahwa pengungkapan CSR berpengaruh negatif dan tidak signifikan terhadap nilai perusahaan.

Terlihat terdapat ketidakkonsistenan hasil antara penelitian-penelitian yang telah dilakukan sebelumnya. Menurut Govindarajan (1986), untuk mengatasi ketidakkonsistenan hasil-hasil penelitian sebelumnya, maka diperlukan pendekatan kontijensi (contingency approach). Pendekatan kontijensi memungkinkan adanya variabel-variabel lain yang dapat bertindak sebagai pemoderasi yang memengaruhi hubungan antara Corporate Social Responsibility dan nilai perusahaan (Wijayanthi, 
I Made Adi Mahendra dan I Gusti Putu Wirawati. Pengaruh...

2016). Ketidakkonsistenan hasil antara penelitian-penelitian sebelumnya menjadi motivasi peneliti untuk melakukan penelitian kembali mengenai pengaruh Corporate Social Responsibility terhadap nilai perusahaan dengan profitabilitas dan free cash flow.

Tingkat pengungkapan CSR yang dilaksanakan oleh setiap perusahaan masih beragam, hal ini disebabkan oleh faktor yang mempengaruhi pengungkapan CSR itu sendiri, salah satunya profitabilitas (Ratna, 2016). Profitabilitas merupakan kemampuan perusahaan dalam memperoleh laba. Semakin tinggi profitabilitas perusahaan maka semakin luas pengungkapan tanggung jawab sosial perusahaan kepada stakeholder (Rani, 2013). Berdasarkan perspektif teori stakeholder, dimana perusahaan dengan profitabilitas tinggi mencerminkan prestasi kinerja yang baik dan sumber daya yang dimiliki perusahaan semakin besar sehingga berdampak pada meningkatnya harapan stakeholder akan kewajiban perusahaan terhadap pengungkapan informasi terkait kegiatan CSR (Ikbal, 2012). Profitabilitas secara signifikan berpengaruh positif terhadap pengungkapan CSR, hal tersebut sejalan dengan penelitian yang dilakukan oleh Iqbal et al. (2012), Rani (2013), Uadiale dan Fagbemi (2012), serta Vintila dan Duca (2013). Penelitian tersebut menjelaskan bahwa semakin tinggi profitabilitas maka pengungkapan CSR yang dilakukan perusahaan semakin banyak. Dengan semakin luas pengungkapan CSR maka semakin tinggi nilai perusahaan.

Perusahaan dengan tingkat profitabilitas yang tinggi merupakan sebuah prestasi kinerja yang baik sehingga perusahaan akan mendapatkan banyak sorotan dari 
ISSN: 2302-8556

E-Jurnal Akuntansi Universitas Udayana Vol.24.3.September (2018):2274-2303

stakeholder, sehingga meningkatkan kewajiban perusahaan atas pelaporan informasi terkait kegiatan CSR. Selain itu, semakin tinggi profitabilitas, maka semakin tinggi pula kedudukan nilai perusahaan di mata investor. Teori sinyal memaparkan bahwa perusahaan dapat memberikan sinyal kepada investor melalui pengungkapan informasi berupa aspek keuangan (informasi laba) dan aspek non keuangan (informasi kegiatan CSR) dengan tujuan untuk meningkatkan nilai perusahaan. Perusahaan yang menyampaikan berita baik (good news) terkait kinerja perusahaan kepada investor diharapkan dapat menjadi sinyal positif terhadap tingkat return investasi yang ditangkap oleh investor, sehingga berdampak pada kenaikan harga saham dan meningkatknya nilai perusahaan.

Arus kas yang dimiliki suatu perusahaan merupakan salah satu sumber dana internal bagi perusahaan tersebut. Hal ini dikarenakan arus kas positif yang dihasilkan oleh perusahaan tersebut dapat digunakan sebagai modal untuk membiayai kegiatan perusahaan. Perusahaan dapat menggunakan arus kasnya untuk melakukan tanggung jawab sosial. Semakin tinggi arus kas positif yang dihasilkan, maka semakin tinggi tanggung jawab sosial yang dapat dilakukan oleh perusahaan. Tingginya penggungkapan tanggung jawab sosial mencerminkan perusahaan tidak hanya berorientasi pada keuntungan tetapi juga memperdulikan kesejahteraan stakeholder dan lingkungannya. Semakin banyak item CSR yang diungkapkan maka semakin baik prospek kinerja perusahaan sehingga dapat meningkatkan nilai perusahaan. Hal ini sesuai dengan penelitian dari Tommy (2010) yang menyatakan bahwa semakin 
I Made Adi Mahendra dan I Gusti Putu Wirawati. Pengaruh...

tinggi arus kas bebas maka semakin tinggi kemampuan keuangan perusahaan dan dapat meningkatkan nilai perusahaan.

Penelitian ini dilakukan pada perusahaan pertambangan yang terdaftar di Bursa Efek Indonesia (BEI) tahun 2014-2016. Perusahaan pertambangan dijadikan objek penelitian dikarenakan sektor ini berkaitan dengan pemanfaatan sumber daya alam yang tidak dapat diperbaharui. Perusahaan pertambangan dalam kegiatan usahanya mempunyai dampak lingkungan baik fisik maupun sosial yang relatif lebih tinggi dibandingkan perusahaan dengan komoditi lain. Oleh karena itu, perusahaan pertambangan wajib melaksanakan dan mengungkapkan CSR sebagai bentuk tanggung jawab perusahaan kepada stakeholder dan lingkungannya.

Teori stakeholder mengatakan bahwa perusahaan bukanlah entitas yang hanya beroperasi untuk kepentingan sendiri namun harus memberikan manfaat bagi stakeholdernya. Dengan demikian, keberadaan suatu perusahaan sangat dipengaruhi oleh dukungan yang diberikan oleh stakeholder kepada perusahaan tersebut (Ghozali dan Chariri, 2007). Tanggung jawab sosial perusahaan merupakan upaya perusahaan untuk memberikan kontribusi positif kepada stakeholder dengan meminimalisir efek negatif yang timbul dari segala kebijakan dan aktfitas operasional perusahaan.

Tanggung jawab sosial perusahaan seharusnya melampui tindakan memaksimalkan laba untuk kepentingan pemegang saham (stakeholder), namun lebih luas lagi bahwa kesejahteraan yang dapat diciptakan oleh perusahaan sebetulnya tidak terbatas kepada kepentingan pemegang saham, tetapi juga untuk kepentingan stakeholder, yaitu semua pihak yang mempunyai keterkaitan atau klaim terhadap 
ISSN: 2302-8556

E-Jurnal Akuntansi Universitas Udayana Vol.24.3.September (2018):2274-2303

perusahaan (Untung, 2008 dalam Waryanti, 2009). Mereka adalah pemasok, pelanggan, pemerintah, masyarakat lokal, investor, karyawan, kelompok politik, dan asosiasi perdagangan. Seperti halnya pemegang saham yang mempunyai hak terhadap tindakan-tindakan yang dilakukan oleh manajemen perusahaan, stakeholder juga mempunyai hak terhadap perusahaan. (Waryanti, 2009).

Stakeholder pada dasarnya dapat mengendalikan atau memiliki kemampuan untuk mempengaruhi pemakaian sumber-sumber ekonomi yang digunakan perusahaan. Power stakeholder dapat berupa kemampuan untuk membatasi pemakaian sumber ekonomi yang terbatas (modal dan tenaga kerja), akses terhadap media yang berpengaruh, dan kemampuan untuk mempengaruhi konsumsi atas barang dan jasa yang dihasilkan perusahaan (Deegan, dalam Ghozali dan Chariri, 2007). Oleh karena itu, perusahaan akan menyesuaikan kegiatan operasionalnya untuk mendapatkan respon positif dari stakeholder.

Teori stakeholder umumnya berkaitan dengan strategi yang diadopsi perusahaan dalam memanage stakeholdernya, strategi tersebut dapat berupa strategi aktif ataupun pasif. Menurut Ullman (1985) dalam Ghozali dan Chariri (2007) strategi aktif diterapkan apabila perusahaan berusaha mempengaruhi hubungan organisasinya dengan stakeholder yang dipandang berpengaruh atau penting. Sedangkan perusahaan yang mengadopsi strategi pasif cenderung tidak terus-menerus memonitor aktivitas stakeholder dan secara sengaja tidak mencari strategi optimal untuk menarik perhatian stakeholder. Kurangnya perhatian terhadap 
I Made Adi Mahendra dan I Gusti Putu Wirawati. Pengaruh...

stakeholdermengakibatkan rendahnya tingkat pengungkapan informasi sosial dan rendahnya kinerja sosial perusahaan.

Suatu informasi dapat dikatakan bermanfaat apabila informasi tersebut benarbenar atau seakan-akan digunakan dalam pengambilan keputusan oleh pemakai. Teori Sinyal membahas mengenai dorongan perusahaan untuk memberikan informasi kepada pihak eksternal. Dorongan tersebut disebabkan karena terjadi asimetri informasi antara pihak manajemen dan pihak eksternal. Asimetri informasi terjadi jika manajemen tidak menyampaikan semua infromasi yang diperoleh secara penuh sehingga mempengaruhi nilai perusahaan yang terefleksi pada perubahan harga saham karena pasar akan merespon informasi yang ada sebagai sinyal. Untuk mengurangi asimetri informasi maka perusahaan harus mengungkapkan informasi yang dimiliki, baik informasi keuangan maupun non keuangan. Salah satu informasi yang wajib untuk diungkapkan oleh perusahaan adalah informasi tentang tanggung jawab sosial perusahaan atau corporate social responsibility. Informasi ini dapat dimuat dalam laporan tahunan perusahaan atau laporan sosial perusahaan terpisah. Perusahaan melakukan pengungkapan Corporate Social Responsibility dengan harapan dapat meningkatkan reputasi dan nilai perusahaan (Rustiarini, 2010).

Nilai perusahaan merupakan harga yang bersedia dibayar investor untuk setiap lembar saham perusahaan. Fama dalam Sherly dan Yulius (2016) menyatakan bahwa nilai perusahaantercermin dari harga sahamnya yang merupakan cerminan dari keputusan investasi, pendanaan, dan manajemen aset. Investor akan tertarik untuk 
ISSN: 2302-8556

E-Jurnal Akuntansi Universitas Udayana Vol.24.3.September (2018):2274-2303

menanamkan modalnya pada perusahaan yang memiliki harga saham cenderung stabil atau terus mengalami peningkatan, hal ini akan berimbas pada nilai perusahaan yang ikut meningkat.

Menurut Nurlela dan Islahuddin (2008) menjelaskan bahwa enterprise value (EV) atau firm value (nilai perusahaan) merupakan konsep penting bagi investor, karena merupakan indikator penting bagi pasar menilai perusahaan secara keseluruhan. Untuk mencapai nilai perusahaan umumnya para pemodal menyerahkan pengelolahannya kepada para professional. Para professional tersebut adalah manajer perusahaan ataupun komisaris. Pada dasarnya tujuan manajemen keuangan adalah memaksimumkan nilai perusahaan. Akan tetapi dibalik tujuan tersebut masih terdapat konflik antara pemilik perusahaan dengan penyedia dana (kreditur). Apabila perusahaan berjalan lancar, maka nilai saham perusahaan akan mengalami peningkatan, sedangkan nilai hutang perusahaan dalam bentuk obligasi tidak terpengaruh sama sekali. Tujuan memaksimumkan harga saham tidak berarti bahwa para manajer harus berupaya mencari kenaikan nilai saham dengan mengorbankan para pemegang obligasi. Dengan demikian, nilai saham perusahaan bisa merupakan indeks yang tepat untuk mengukur tingkat efektifitas perusahaan.

CSR yaitu suatu bentuk aktivitas yang dilakukan perusahaan untuk meningkatkan ekonomi perusahaan sekaligus peningkatan kualitas hidup karyawan beserta keluarganya dan juga kualitas hidup masyarakat sekitar. Menurut Cheng dan Yulius (2011), adapun manfaat yang diberikan dengan adanya aktivitas CSR, seperti: 
I Made Adi Mahendra dan I Gusti Putu Wirawati. Pengaruh...

dapat meningkatkan citra dan daya tarik perusahaan di mata investor serta analis keuangan penjualan, dapat menunjukan brand positioning, dan dapat meningkatkan penjualan dan market share. Pengungkapan CSR merupakan proses pemberian informasi kepada kelompok yang berkepentingan tentang aktivitas perusahaan serta memberikan informasi tentang dampaknya terhadap sosial dan lingkungan (Mathews, 1995).

Menurut The World Business Council for Sustainable Development (WBCSD), Corporate Social Responsibility atau tanggung jawab sosial perusahaan merupakan komitmen bisnis untuk memberikan kontribusi bagi pembangunan ekonomi berkelanjutan, melalui kerja sama dengan para karyawan serta perwakilan mereka, keluarga mereka, komunitas setempat, maupun masyarakat umum untuk meningkatkan kualitas kehidupan dengan cara yang bermanfaat baik bagi bisnis sendiri maupun untuk pembangunan. Tanggung jawab sosial perusahaan atau Corporate Social Responsibility merupakan suatu konsep bahwa organisasi, khususnya perusahaan memiliki suatu tanggung jawab terhadap konsumen, karyawan, pemegang saham, komunitas, dan lingkungan dalam segala aspek operasional perusahaan. Konsep tanggung jawab keuangan, sosial dan lingkungan tersebut dikenal dengan konsep Triple Bottom Line (3P :Planet, People, Profit).

Profitabilitas adalah faktor yang memberikan kebebasan dan fleksibilitas kepada manajemen untuk melakukan dan mengungkapkan kepada pemegang saham program tanggung jawab sosial secara lebih luas (Florence, et al. 2004). Profitabilitas 
ISSN: 2302-8556

E-Jurnal Akuntansi Universitas Udayana Vol.24.3.September (2018):2274-2303

perusahaan merupakan salah satu faktor yang mempengaruhi pengungkapkan tanggung jawab sosial (Lucyanda dan Siagian, 2012). Semakin tinggi tingkat profitabilitas suatu perusahaan, maka semakin tinggi pula keinginan untuk melakukan pengungkapkan tanggung jawab sosial perusahaan (Purwanto, 2011). Kamil dan Herusetya (2012) berpendapat bahwa tingkat profitabilitas yang semakin besar menunjukkan perusahaan mampu mendapatkan laba yang semakin besar, sehingga perusahaan mampu untuk meingkatkan aktivitas tanggung jawab sosail, serta mengungkapkan tanggung jawab sosialnya dalam laporan tahunan dengan lebih luas.

Nikolis (2013) rasio profitabilitas memiliki beberapa macam jenis meliputi Return on Assets (ROA), Return on Equity (ROE), Profit Margin dan Earning per Share (EPS).Rasio profitabilitas mampu mencerminkan keberhasilan perusahaan dalam menghasilkan keuntungan. Semakin besar keuntungan yang didapatkan semakin besar kemampuan perusahaan membayarkan devidennya. Profitabilitas dapat menjadi pertimbangan bagi investor dalam berinvestasi. Penelitian ini menggunakan ROA sebagai ukuran profitabilitas perusahaan, ROA merupakan rasio antara laba bersih terhadap total aktiva. Semakin besar ROA menunjukkan profitabilitas perusahaan semakin baik. ROA merupakan gambaran dari kondisi perusahaan saat ini dan bisa digunakan sebagi acuan untuk memprediksi masa depan perusahaan. Hubungan antara profitabilitas perusahaan dengan pengungkapan CSR perusahaan untuk mencerminkan pandangan reaksi sosial memerlukan gaya manajerial. Sehingga semakin tinggi tingkat profitabilitas perusahaan maka semakin besar pengungkapan informasi perusahaan (Anggraini, 2006). 
I Made Adi Mahendra dan I Gusti Putu Wirawati. Pengaruh...

Kieso (2007:477) mendefinisikan arus kas bebas (free cash flow) sebagai jumlah arus kas perusahaan yang digunakan untuk melunasi utang, membeli investasi tambahan, membeli saham treasuri, atau hanya untuk menambah likuiditas perusahaan. Tingginya arus kas bebas menunjukkan perusahaan tersebut memiliki surplus dana internal yang tinggi. Surplus ini meningkatkan kemampuan perusahaan dalam melunasi atau membayar kewajiban jangka pendek dan jangka panjangnya. Kemampuan suatu perusahaan dalam melunasi kewajiban menunjukkan perusahaan mampu menghadapi kesulitan keuangan di masa depan. Semakin tinggi kemampuan perusahaan dalam menghadapi kesulitan keuangan atau risiko kebangkrutan akan mendapatkan respon positif dari investor. Rendahnya risiko kebangkrutan suatu perusahaan akan menunjukkan rendahnya risiko investasi dari investor. Perusahaan dengan kesulitan keuangan yang rendah sangat disukai oleh investor karena dapat memperoleh capital gain yang lebih tinggi dibandingkan dengan perusahaan yang memiliki kesulitan keuangan yang lebih tinggi.

Tanggung jawab sosial perusahaan diungkapkan antara lain di dalam laporan yang disebut Sustainability Reporting. CSR dapat menjadi berkelanjutan apabila program yang dibuat oleh suatu perusahaan benar-benar merupakan komitmen bersama dari segenap unsur yang ada di dalam perusahaan itu sendiri.

Tujuan utama perusahaan adalah meningkatkan nilai perusahaaan. Nilai perusahaan akan terjamin tumbuh secara berkelanjutan (sustainable) apabila perusahaan memperhatikan dimensi ekonomi, sosial dan lingkungan hidup karena keberlanjutan merupakan keseimbangan antara kepentingan ekonomi, lingkungan dan 
ISSN: 2302-8556

E-Jurnal Akuntansi Universitas Udayana

Vol.24.3.September (2018):2274-2303

masyarakat. Dimensi tersebut terdapat di dalam penerapan Corporate Social Responsibility yang dilakukan perusahaan sebagai bentuk pertanggungjawaban dan kepedulian terhadap lingkungan di sekitar perusahaan. Banyak manfaat yang diperoleh perusahaan dengan pelaksanaan corporate social responsibility, antara lain produk semakin disukai oleh konsumen dan perusahaan diminati investor.

Perusahaan yang melakukan CSR dianggap mampu memberikan kontribusi yang baik bagi masyarakat umum dan mampu bertanggungjawab atas aktivitas dan dampak yang ditimbulkan terhadap lingkungan sekitar. Pelaksanakan praktik CSR akan meyakinkan investor bahwa perusahaan akan mampu menjamin kelangsungan hidup perusahaan kedepannya yang sekaligus akan meningkatkan nilai perusahaan. Penelitian terebut sejalan dengan penelitian yang dilakukan oleh Nguyen et al. (2005), Fodio et al. (2013), Silvia 2012), Gherghina et al. (2014), Harjoto dan Jo (2011) serta Servaes dan Tamayo (2013), dan Nurlela dan Islahuddin (2008) yang menyatakan bahwa dengan adanya praktik CSR yang baik, diharapkan nilai perusahaan akan dinilai dengan baik oleh investor.

$\mathrm{H}_{1}$ : Corporate Social Responsibility berpengaruh positif terhadap nilai perusahaan.

Profitabilitas perusahaan merupakan kemampuan perusahaan dalam menghasilkan laba bersih dari aktivitas yang dilakukan pada periode akuntansi. Profitabilitas dapat menjadi pertimbangan penting bagi investor dalam keputusan investasinya, karena semakin besar dividen (dividend payout) akan semakin menghemat biaya modal, di sisi lain para manajer (insider) menjadi meningkat powernya bahkan bisa meningkatkan kepemilikannya akibat penerimaan deviden 
I Made Adi Mahendra dan I Gusti Putu Wirawati. Pengaruh...

sebagai hasil keuntungan yang tinggi. Dengan tawaran mendapatkan hasil keuntungan yang tinggi, diharapkan dapat menarik minat investor dalam berinvestasi.

Semakin tinggi tingkat profitabilitas perusahaan maka perusahaan akan mampu mengungkapkan sosial perusahaan semakin luas dan semakin baik pula kinerja yang dilakukan perusahaan didalam memperbaiki lingkungannya (kinerja ekonomi, lingkungan dan sosial), maka nilai perusahaan akan semakin meningkat sebagai akibat dari para investor yang menanamkan sahamnya pada perusahaan. Hal tersebut dikarenakan para investor lebih tertarik untuk menginvestasikan modalnya pada korporasi yang ramah lingkungan, dan begitupula sebaliknya semakin rendah tingkat profitabilitas yang dimiliki perusahaan maka perusahaan akan mengungkapkan sosial perusahaan lebih rendah, maka nilai perusahaan semakin rendah sebagai akibat dari para investor yang enggan menamamkan sahamnya pada perusahaan yang kurang ramah lingkungan .

Menurut Bowman dan Haire (1976) semakin tinggi tingkat profitabilitas perusahaan maka semakin besar pengungkapan informasi sosial yang dilakukan perusahaan. Sehingga dapat disimpulkan bahwa, Corporate Social Responsibility akan meningkatkan nilai perusahaan pada saat profitabilitas perusahaan meningkat. Hasil penelitian Dahlia dan Siregar (2008) juga mengindikasikan bahwa perilaku etis perusahaan berupa tanggung jawab sosial terhadap lingkungan sekitarnya memberikan dampak positif, yang dalam jangka panjang akan tercermin pada keuntungan perusahaan (profit) dan peningkatan kinerja keuangan. 
ISSN: 2302-8556

E-Jurnal Akuntansi Universitas Udayana Vol.24.3.September (2018):2274-2303

$\mathrm{H}_{2}$ : Profitabilitas memperkuat pengaruh Corporate Social Responsibility terhadap nilai perusahaan.

Menurut White et. al. (2003:186), tingginya free cash flow menandakan perusahaan memiliki cukup dana untuk pertumbuhan, pembayaran utang dan pembagian dividen. Arus kas yang dimiliki suatu perusahaan merupakan salah satu sumber dana internal bagi perusahaan tersebut. Hal ini dikarenakan arus kas positif yang dihasilkan oleh perusahaan tersebut dapat digunakan sebagai modal untuk membiayai kegiatan perusahaan. Perusahaan dapat menggunakan arus kasnya untuk melakukan tanggung jawab sosial. Semakin tinggi arus kas positif yang dihasilkan, maka semakin tinggi tanggung jawab sosial yang dapat dilakukan oleh perusahaan. Tingginya penggungkapan tanggung jawab sosial mencerminkan perusahaan tidak hanya berorientasi pada keuntungan tetapi juga memperdulikan kesejahteraan stakeholder dan lingkungannya. Semakin banyak item CSR yang diungkapkan maka semakin baik prospek kinerja perusahaan di masa mendatang dan semakin baik pula persepsi investor terhadap perusahaan yang tercermin dari meningkatnya harga saham dan nilai perusahaan. Oleh karena itu, tingginya free cash flow dapat memperkuat pengaruh Corporate Social Responsibility terhadap nilai perusahaan. Hal ini didukung oleh penelitian dari Tommy (2010) yang mengungkapkan bahwa free cash flow berpengaruh positif terhadap nilai perusahaan.

$\mathrm{H}_{3}$ : Free Cash Flow dapat memperkuat pengaruh Corporate Social Responsibility terhadap nilai perusahaan. 
I Made Adi Mahendra dan I Gusti Putu Wirawati. Pengaruh...

\section{METODE PENELITIAN}

Lokasi penelitian dilakukan dengan mengunduh data laporan keuangan dari situs resmi Bursa Efek Indonesia (BEI) yaitu www.idx.co.id, sedangkan ruang lingkup dalam penelitian ini adalah perusahaan pertambangan yang terdaftar di Bursa Efek Indonesia 2013 - 2016.Obyek penelitian dalam penelitian ini adalah corporate social responsibility, profitabilitas, free cash flow dan nilai perusahaan yang terdaftar di Bursa Efek Indonesia periode 2013 - 2016. Data diperoleh dari laporan tahunan perusahaan yang didapatkan melalui situswww.idx.co.id.

Populasi dalam penelitian ini adalah seluruh perusahaan pertambangan yang terdaftar di Bursa Efek Indonesia. Lokasi ini dipilih karena aktivitas perusahaan pertambangan yang mengeksploitasi sumber daya menyebabkan kerusakan yang berdampak pada lingkungan sekitarnya, sehingga perlu adanya pemberdayaan berupa Corporate Social Responsibility. Yulia (2013) menyatakan sektor pertambangan mampu memberikan keuntungan besar jangka panjang bagi para investor sehingga laporan keuangan tersebut menjadi bahan pertimbangan. Selain itu, hasil survey pada tahun 2007 yang dilakukan oleh Fraser Institute yang menyatakan bahwa Indonesia sebagai negara yang berpotensi menjadi pusat pertambangan berskala dunia (sumber: The Indonesian Mining Magazine, Mei 2008). Sampel dalam penelitian ini ditentukan menggunakan metode nonprobability sampling dengan teknik purposive sampling, yaitu teknik pengumpulan sampel atas dasar kriteria tertentu.

Metode pengumpulan data dalam penelitian ini adalah metode dokumentasi. Metode dokumentasi adalah pengumpulan data yang dilakukan dengan cara 
mengumpulkan dokumen-dokumen dan catatan-catatan yang didalamnya terdapat informasi yang diperlukan dalam penelitian. Teknik dokumentasi dalam penelitian ini dilakukan dengan cara pengumpulan, pencatatan dan pengcopyan data dalam laporan keuangan maupun laporan tahunan perusahaan pertambangan yang diperoleh dengan mengakses situs www.idx.co.id.

Moderated Regression Analysis (MRA) merupakan regresi linier berganda dimana dalam persamaan regresinya mengandung unsur interaksi dua atau lebih variabel independen (Ghozali, 2013:225). Analisis regresi ini bertujuan untuk mengetahui pengaruh profitabilitas danfree cash flow dalam memoderasi pengaruh Corporate Social Responsibility terhadap nilai perusahaan. Persamaan regresinya dapat dirumuskan sebagai berikut:

$$
\mathrm{Y}=\alpha+\beta_{1} \mathrm{X}_{1}+\beta_{2} \mathrm{X} 2+\beta_{3} \mathrm{X} 3+\beta_{4} \mathrm{X}_{1} * \mathrm{X} 2+\beta_{5} \mathrm{X}_{1} * \mathrm{X} 3+\varepsilon \ldots \ldots \ldots \ldots \ldots \ldots \ldots \ldots
$$

$$
\begin{aligned}
& \text { Keterangan: } \\
& \mathrm{Y} \quad=\text { Nilai Perusahaan } \\
& \alpha \quad=\text { Konstanta } \\
& \beta_{1,2,3,4,5}=\text { Koefisien Regresi } \\
& \mathrm{X}_{1} \quad=\text { Corporate Social Responsibility (CSR) } \\
& \mathrm{X} 2=\text { Profitabilitas } \\
& \mathrm{X} 3=\text { Free Cash Flow } \\
& \mathrm{X}_{1} * \mathrm{X}_{2}=\text { Interaksi antara CSR dengan profitabilitas } \\
& \mathrm{X}_{1} * \mathrm{X}_{3}=\text { Interaksi antara CSR dengan free cash flow } \\
& \varepsilon=\text { error }
\end{aligned}
$$

\section{HASIL PENELITIAN DAN PEMBAHASAN}

Hasil analisis sampel dengan menggunakan purposive sampling disajikan pada Tabel 1. 


\section{Tabel 1.}

\section{Hasil Seleksi Pemilihan Sampel}

\section{Kriteria Sampel}

Populasi penelitian adalah perusahaan pertambangan yang terdaftar di Bursa Jumlah Efek Indonesia (BEI) selama tahun pengamatan dari tahun 2013 sampai dengan tahun 2016.

1 Perusahaan petambangan yang sustainability report-nya tidak tersedia di web BEI secara terus-menerus selama tahun pengamatan dari tahun 2013 sampai dengan 2016.

2 Perusahaan pertambangan yang tidak memiliki informasi lengkap mengenai data-data yang diperlukan dalam penelitian, seperti kepemilikan asing dan kepemilikin manajemen.

Sampel yang digunakan

44

Jumlah tahun pengamatan (2013-2016)

Jumlah sampel selama periode penelitian

Sumber: Data diolah, 2018

Berdasarkan hasil dari proses seleksi sampel dengan purposive sampling yang dapat diihat pada Tabel 1., diperoleh perusahaan sebagai sampel penelitian pada tahun 2013-2016 adalah sebanyak 8 perusahaan pertambangan akibat dari ketersediaan informasi Corporate Social Responsibility yang masih relatif jarang ditemukan dalam annual report perusahaan. Jadi, sesuai dengan kriteria jumlah observasi dalam penelitian selama tahun 2013-2016 adalah 32 observasi.

Uji statistik deskriptif bertujuan untuk memberikan informasi karakteristik variable penelitian khususnya mengenai rata-rata (mean), minimum, maksimum, dan standar deviasi. Hasil statistik deskriptif masing-masing variable disajikan pada Tabel 2. 
ISSN: 2302-8556

E-Jurnal Akuntansi Universitas Udayana

Vol.24.3.September (2018):2274-2303

Tabel 2.

Hasil Statistik Deskriptif

\begin{tabular}{|c|c|c|c|c|c|}
\hline Variabel & $\mathbf{N}$ & $\begin{array}{l}M \\
\text { in. }\end{array}$ & $\begin{array}{r}\text { M } \\
\text { aks. }\end{array}$ & $\begin{array}{l}\text { Rata- } \\
\text { rata }\end{array}$ & $\begin{array}{l}\text { Simpangan } \\
\text { Baku }\end{array}$ \\
\hline $\operatorname{CSR}\left(X_{1}\right)$ & 32 & 0,09 & $2^{0,6}$ & 0,3457 & 0,1238 \\
\hline $\operatorname{Profitabilitas}\left(\mathbf{X}_{2}\right)$ & 32 & $0,16^{-}$ & $7^{0,1}$ & 0,0193 & 0,0704 \\
\hline Free Cash Flow $X_{3}$ ) & 32 & $1,33^{-}$ & $4^{0,7}$ & 0,0901 & 0,4067 \\
\hline Nilai Perusahaan (Y) & 32 & 0,53 & $4^{3,1}$ & 1,3375 & 0,6802 \\
\hline
\end{tabular}

Sumber: Data diolah, 2018

Tabel 2. menunjukkan statistik deskriptif dari variabel dependen, independen, dan moderasi dalam penelitian ini. Beberapa penjelasan mengenai hasil perhitungan statistik diuraikan data pada variabel Corporate Social Responsibility $\left(\mathrm{X}_{1}\right)$ memiliki nilai rata-rata sebesar 0,3457 dan simpangan baku sebesar 0,1238 . Nilai minimum variabel Corporate Social Responsibility dimiliki oleh perusahaan INCO pada tahun 2016 sebesar 0,09 sedangkansedangkan nilai maksimum dimiliki oleh perusahaan TINS pada tahun 2016 sebesar 0,62.

Data pada variabel Profitabilitas $\left(\mathrm{X}_{2}\right)$ memiliki nilai rata-rata sebesar 0,0193 dan simpangan baku sebesar 0,0704. Nilai minimum variabel Profitabilitas dimiliki oleh perusahaan BYAN pada tahun 2014 sebesar -0,16 sedangkansedangkan nilai maksimum dimiliki oleh perusahaan ITMG pada tahun 2013 sebesar 0,17.

Data pada variabel Free Cash Flow $\left(\mathrm{X}_{3}\right)$ memiliki nilai rata-rata sebesar 0,0901 dan simpangan baku sebesar 0,4067. Nilai minimum variabel Free Cash Flow dimiliki oleh perusahaan CTTH pada tahun 2013 sebesar -1,33 sedangkansedangkan nilai maksimum dimiliki oleh perusahaan PTRO pada tahun 2013 sebesar 0,74. 
I Made Adi Mahendra dan I Gusti Putu Wirawati. Pengaruh...

Data pada variabel Nilai Perusahaan (Y) memiliki nilai rata-rata sebesar 1,3375 dan simpangan baku sebesar 0,6802. Nilai minimum variabel Nilai Perusahaan dimiliki oleh perusahaan KKGI pada tahun 2015 sebesar 0,53 sedangkansedangkan nilai maksimum dimiliki oleh perusahaan CTTH pada tahun 2013 sebesar 3,14. Teknik analisis data sederhana digunakan untuk mengetahui pengaruh Corporate Social Responsibility (X) terhadap nilai perusahaan (Y) apakah hipotesis yang dibuat akan diterima atau ditolak. Analisis ini dilakukan untuk mengetahui hubungan antara profitabilitas dengan nilai perusahaan. Hasil pengujian regresi sederhana ditunjukkan pada Tabel 3.

Tabel 3.

Hasil Analisis Regresi Sederhana

\begin{tabular}{|c|c|c|c|c|c|}
\hline \multirow{2}{*}{ Model } & \multicolumn{2}{|c|}{$\begin{array}{l}\text { Unstandardized } \\
\text { Coefficients }\end{array}$} & \multirow{2}{*}{$\begin{array}{c}\text { Standardized } \\
\text { Coefficients } \\
\text { Beta }\end{array}$} & \multirow[b]{2}{*}{$\mathbf{t}$} & \multirow[b]{2}{*}{ Sig. } \\
\hline & B & Std. Error & & & \\
\hline (Constant) & 2,1 & 13,256 & & 0,165 & 0,870 \\
\hline $\mathrm{X}_{1}$ & $\begin{array}{l}86 \\
0,6 \\
49\end{array}$ & 0,114 & 0,720 & 5,682 & 0,000 \\
\hline F Hitung & & 32,288 & & & \\
\hline Signifikansi F & & 0,000 & & & \\
\hline RSquare & & 0,518 & & & \\
\hline Adjusted R Square & & 0,502 & & & \\
\hline
\end{tabular}

Sumber: Data diolah, 2018

Berdasarkan hasil analisis regresi sederhana seperti yang disajikan pada Tabel

3., maka persamaan strukturalnya adalah sebagai berikut:

$\mathrm{Y}=2,186+0,251 \mathrm{X}_{1}$

Persamaan diatas dapat menjelaskan bahwa jika nilai konstanta persamaan regresi linier sederhana sebesar nol maka nilai perusahaan sebesar 2,186. Apabila Corporate Social Responsibility tidak mengalami perubahan maka nilai perusahaan 
ISSN: 2302-8556

E-Jurnal Akuntansi Universitas Udayana Vol.24.3.September (2018):2274-2303

dinyatakan tetap dan tidak mengalami perubahan. Jika Corporate Social Responsibility mengalami kenaikan satu satuan maka nilai perusahaan mengalami kenikan sebesar 0,251. Pengukuran koefisien determinasi dilakukan untuk mengetahui persentase pengaruh Corporate Social Responsibility terhadap perubahan nilai perusahaan. Dari hal ini dapat diketahui seberapa besar variabel nilai perusahaan mampu dijelaskan oleh variabel Corporate Social Responsibility. Hasil pengujian koefisien determinasi dapat dilihat pada Tabel 4.5 berikut. Berdasarkan Tabel 4.5 diperoleh hasil Adjusted $R$ Square sebesar 0,502 atau 50,2 persen artinya kontribusi variabel Corporate Social Responsibility dapat mempengaruhi nilai perusahaan sebesar 50,2 persen sedangkan sisanya sebesar 49,8 persen dipengaruhi oleh variabel lain yang tidak termasuk dalam model penelitian.

Metode analisis data dalam penelitian ini menggunakan teknik analisis regresi analisis regresi moderasi MRA (Moderated Regression Analysis), yaitu mengetahui pengaruh Corporate Social Responsibility, Profitabilitas, Free Cash Flow, Interaksi Corporate Social Responsibility dengan Profitabilitas, dan Interaksi Corporate Social Responsibility dengan Free Cash Flow terhadap Nilai Perusahaan. Perhitungan koefisien regresi dilakukan dengan analisis regresi melalui software SPSS 18.0for Windows, diperoleh hasil yang ditunjukan pada Tabel 4. berikut: 
I Made Adi Mahendra dan I Gusti Putu Wirawati. Pengaruh...

Tabel 4.

Hasil Moderated Regression Analysis (MRA)

\begin{tabular}{lrccrc}
\hline Model & \multicolumn{2}{c}{$\begin{array}{c}\text { Unstandardized } \\
\text { Coefficients }\end{array}$} & $\begin{array}{c}\text { Standardize } \\
\text { d Coefficients }\end{array}$ & & \\
& B & $\begin{array}{c}\text { Std. } \\
\text { Error }\end{array}$ & Beta & t & Sig. \\
\hline (Constant) & - & 0,083 & & - & 0,885 \\
& 0,012 & & & 0,146 & \\
$\mathrm{X}_{1}$ & 0,251 & 0,082 & 0,286 & 3,073 & 0,005 \\
$\mathrm{X}_{2}$ & 0,556 & 0,081 & 0,530 & 6,823 & 0,000 \\
$\mathrm{X}_{3}$ & 0,071 & 0,117 & 0,049 & 0,607 & 0,549 \\
$\mathrm{X}_{1} * \mathrm{X}_{2}$ & 0,171 & 0,076 & 0,173 & 0,241 & 0,034 \\
$\mathrm{X}_{1} * \mathrm{X}_{3}$ & 0,190 & 0,087 & 0,189 & 0,184 & 0,038 \\
F Hitung & \multicolumn{7}{c}{0,096} & & & \\
Signifikansi F & 0,000 & & & \\
RSquare & 0,890 & & & \\
Adjusted R Square & 0,869 & &
\end{tabular}

Berdasarkan hasil analisis regresi moderasi seperti yang disajikan pada Tabel 4.6, maka persamaan strukturalnya adalah sebagai berikut:

$$
Y=-0,012+0,251 X_{1}+0,556 X_{2}+0,071 X 3+0,171 X_{1} * X 2+0,190 X_{1} * X 3
$$

Berdasarkan persamaan diatas, dapat dijelaskan interpretasi sebagai bahwa konstanta sebesar -0,012 memiliki arti apabila Corporate Social Responsibility $\left(\mathrm{X}_{1}\right)$, Profitabilitas $\left(\mathrm{X}_{2}\right)$, dan Free Cash Flow $\left(\mathrm{X}_{3}\right)$ besarnya sama dengan nol satuan, atau apabila Corporate Social Responsibility $\left(\mathrm{X}_{1}\right)$, Profitabilitas $\left(\mathrm{X}_{2}\right)$, dan Free Cash Flow $\left(\mathrm{X}_{3}\right)$ konstan, maka nilai Nilai Perusahaan (Y) sebesar -0,012 satuan.Nilai koefisien regresi Corporate Social Responsibility $\left(\mathrm{X}_{1}\right)$ sebesar 25,1 persen memiliki arti apabila Corporate Social Responsibility meningkat sebesar 1 persen dengan anggapan variabel lainnya konstan, maka Nilai Perusahaan (Y) meningkat sebesar 25,1 persen. 
ISSN: 2302-8556

E-Jurnal Akuntansi Universitas Udayana Vol.24.3.September (2018):2274-2303

Nilai koefisien regresi Profitabilitas $\left(\mathrm{X}_{2}\right)$ sebesar 55,6memiliki arti apabila Profitabilitas meningkat sebesar 1 persen dengan anggapan variabel lainnya konstan, maka Nilai Perusahaan (Y) meningkat sebesar 55,6 persen.

Nilai koefisien regresi Free Cash Flow $\left(\mathrm{X}_{3}\right)$ sebesar 7,1memiliki arti apabila Free Cash Flow meningkat sebesar 1 persen dengan anggapan variabel lainnya konstan, maka Nilai Perusahaan (Y) meningkat sebesar 7,1 persen.

Nilai koefisien regresi $\mathrm{X}_{1} * \mathrm{X}_{2}$ sebesar 17,1 mengindikasikan bahwa apabila hubungan Corporate Social Responsibility dengan Profitabilitas meningkat sebesar 1 persen, maka Nilai Perusahaan (Y) mengalami peningkatan sebesar 17,1 persen.

Nilai koefisien regresi $\mathrm{X}_{1} * \mathrm{X}_{3}$ sebesar 19,0 mengindikasikan bahwa apabila hubungan Corporate Social Responsibility dengan Free Cash Flow meningkat sebesar 1 persen, maka Nilai Perusahaan (Y) mengalami peningkatan sebesar 19,0 persen.

Hasil uji memberikan hasil dimana diperoleh besarnya adjusted $\mathrm{R}^{2}$ (koefisien determinasi yang telah disesuaikan) pada Tabel adalah 0,869. Ini berarti variasi Nilai Perusahaan dapat dipengaruhi secara signifikan oleh variabel Corporate Social Responsibility, Profitabilitas, Free Cash Flow, Interaksi Corporate Social Responsibility dengan profitabilitas, dan Interaksi Corporate Social Responsibility dengan Free Cash Flow sebesar 86,9 persen, sedangkan sisanya sebesar 13,1 persen dijelaskan oleh faktor-faktor lain.

Hasil uji F (Ftest) menunjukkan bahwa nilai $\mathrm{F}$ hitung sebesar 42,096 dengan nilai signifikansi $\mathrm{P}$ value 0,000 yang lebih kecil dari $\alpha=0,05$, ini berarti model yang 
I Made Adi Mahendra dan I Gusti Putu Wirawati. Pengaruh...

digunakan pada penelitian ini adalah layak. Hasil ini memberikan makna bahwa seluruh variabel independen mampu memprediksi atau menjelaskan fenomena nilai perusahaan.

Berdasarkan Tabel 3. pengaruh Penerapan Corporate Social Responsibility terhadap Nilai Perusahaan diperoleh nilai Sig. sebesar 0,005 dengan nilai koefisien beta 0,251 . Nilai Sig. $0,005<0,050$ mengindikasikan bahwa $\mathrm{H}_{1}$ diterima. Hasil ini mempunyai arti bahwa Corporate Social Responsibility berpengaruh positif dan signifikan terhadap Nilai Perusahaan.

Berdasarkan Tabel 3. pengaruh Profitabilitas terhadap Nilai Perusahaan diperoleh nilai Sig. sebesar $0,000<0,05$. Hasil ini mempunyai arti bahwa Profitabilitas berpengaruh positif dan signifikan terhadap Nilai Perusahaan. Interaksi Corporate Social Responsibility dengan profitabilitas $\left(\beta_{4}\right)$ positif sebesar 0,171 dengan nilai signifikansi 0,034 < 0,05, maka dapat disimpulkan bahwa variabel Profitabilitas $\left(\mathrm{X}_{2}\right)$ dapat memoderasi pengaruh penerapan corporate social responsibility pada Nilai Perusahaan. Nilai koefisien Profitabilitas yang signifikan pada variabel bebas dan signifikan pada variabel interaksinya menandakan bahwa Profitabilitas adalah quasi moderasi. Selain itu, karena tanda dari koefisien interaksinya positif, maka hal ini berarti Profitabilitas mampu memoderasi (memperkuat) pengaruh Corporate Social Responsibility pada Nilai Perusahaan, sehingga $\mathrm{H}_{2}$ diterima.

Berdasarkan Tabel 4. pengaruh Free Cash Flow terhadap Nilai Perusahaan diperoleh nilai Sig. sebesar 0,549>0,05. Hasil ini mempunyai arti bahwa Free Cash Flow tidak berpengaruh terhadap Nilai Perusahaan. Interaksi Corporate Social 
ISSN: 2302-8556

E-Jurnal Akuntansi Universitas Udayana Vol.24.3.September (2018):2274-2303

Responsibility dengan Free Cash Flow ( $\left.\beta_{5}\right)$ positif sebesar 0,190 dengan nilai signifikansi $0,038<0,05$, maka dapat disimpulkan bahwa variabel Free Cash Flow $\left(\mathrm{X}_{3}\right)$ dapat memoderasi pengaruh Corporate Social Responsibility pada Nilai Perusahaan. Nilai koefisien Free Cash Flow yang tidak signifikan pada variabel bebas dan nilai koefisien yang signifikan pada variabel interaksinya menandakan bahwa Free Cash Flow adalah pure moderasi. Selain itu, karena tanda dari koefisien interaksinya positif, maka hal ini berarti Free Cash Flow mampu memoderasi (memperkuat) pengaruh Corporate Social Responsibility pada Nilai Perusahaan, sehingga $\mathrm{H}_{3}$ diterima.

\section{SIMPULAN}

Berdasarkan hasil penelitian yang diperoleh melalui pengujian statistik serta pembahasan seperti yang telah diuraikan pada bab sebelumnya, maka dapat disimpulkan bahwacorporate Social Responsibility berpengaruh positif dan signifikan pada Nilai Perusahaan. Profitabilitas mampu memoderasi (memperkuat) pengaruh Corporate Social Responsibility pada Nilai Perusahaan.Free Cash Flow mampu memoderasi (memperkuat) pengaruh Corporate Social Responsibility pada Nilai Perusahaan Berdasarkan hasil penelitian dan simpulan diatas, maka saran yang dapat diberikan adalah kepada manajemen perusahaan terus meningkatkan pelaksanaan corporate social responsibility agar perusahaan lebih dikenal secara luas oleh masyarakat sehingga dapat meningkatkan nilai perusahaan.

Lokasi penelitian terbatas hanya pada perusahaan pertambangan yang terdaftar di Bursa Efek Indonesia. Peneliti selanjutnya agar dapat melakukan penelitian pada 
I Made Adi Mahendra dan I Gusti Putu Wirawati. Pengaruh...

sektor perusahaan yang berbeda, seperti sektor manufaktur, sektor pertanian, sektor properti, sektor perdagangan, dan lain-lain.Penelitian selanjutnya diharapkan dapat mempertimbangkan penggunaan variabel moderasi lain, seperti Good Corporate Governance (GCG).

\section{REFERENSI}

Anggraini, F. R. R. 2006. Pengungkapan Informasi Sosial dan Faktor-Faktor yang Mempengaruhi Pengungkapan Informasi Sosial dalam Laporan Keuangan Tahunan (The Disclosure of Social Information and Factors Affecting the Disclosure of Social Information in Annual Report). Simposium Nasional Akuntansi IX Padang, 23-26.

Brigham, Eugene dan Houston Joel. 2001. Manajemen Keuangan. Jakarta: Erlangga

Bowman, E.H., \& Haire, M.A. 1976. Strategic Posture Toward Corporate Social Responsibility. California Management Review, 18 (2), 49-58.

Chairiri, Anis dan Imam Ghozali. 2007. Teori Akuntansi. Semarang: Universitas Diponegoro.

Cheng, Megawati dan Yulius Logi Christiawan. 2011. Pengaruh Pengungkapan Corporate Social Responsibility Terhadap Abnormal Return. Jurnal Akuntansi dan Keuangan, 13(3), 24-36.

Dahlia, L. dan Siregar, V. S. 2008. Pengaruh Corporate Social Responsibility Terhadap Kinerja Perusahaan (Studi Empiris pada Perusahaan yang Tercatat di Bursa Efek Indonesia pada Tahun 2005-2006). Simposium Nasional Akuntansi XI. Pontianak.

Florence, D. Suryanto dan Zulaikha. 2004. Pengaruh Karakteristik Perusahaan Terhadap Pengungkapan Sosial dalam Laporan Tahunan Perusahaan Go Public di Bursa Efek Jakarta . Jurnal Maksi. 4, 161-177.

Fodio, Musa Inuwa, Abdullahi Musa- bu Abdiss Amad dan Victor Chiedu Oba. 2013. Corporate Social Responsibility and Firm Value in Quoted Nigerian Financial Services. International Journal of Finance and Accounting, 2(7), 331-340.

Gherghina, Stefan Christian, Georgeta Vintila and Diana Dobrescu. 2015. An Empirical Research on the Relationship Between Corporate Social 
ISSN: 2302-8556

E-Jurnal Akuntansi Universitas Udayana

Vol.24.3.September (2018):2274-2303

Responsibility Ratings and U.S. Listed Companies Value. Journal of Economics Studies and Research, 10(1), 1-11.

Ghozali, I. dan A. Chariri. 2007. Teori Akuntansi. Semarang: Badan Penerbit Universitas Diponegoro.

Harjoto, Maretno A. and Hoje Jo. 2011. Corporate Governance and Firm Value: The Impact of Corporate Social Responsibility. Journal of Business Ethic, 5(1), 258-270.

Kamil, Ahmad dan Antonius Herusetya. 2012. Pengaruh Karakteristik Perusahaan Terhadap Luas Pengungkapan Kegiatan Corporate Social Responsibility. Media Riset Akuntansi, 2(1), 1-17.

Keown, Arthur J., Martin, J. D., Petty, J. William, David F. Scott JR. 2004. Manajemen Keuangan Jilid 1. Jakarta: Indeks.

Kieso, Donald E., Jerry J. Weygandt, and Terry D. Warfield. 2007. Akuntansi Intermediate. Edisi Dua Belas. Jakarta: Salemba Empat.

Kurniasari, Widuri dan Yusni Warastuti. 2015. The Relationship Between CSR and Profitability To Firm Value in Sri Kehati Index. International Journal of Economic Behaviour, 5(1), 31-41.

Mathews, M.R. 1995. Social and Environmental Accounting: A Practical Demonstration of Ethical Concern. Journal of Business Ethics, 14(8), 663-671.

Mulyadi, Martin Surya dan Yunita Anwar. 2012. Impact Of CSR Toward Firm Value and Profitability. The Business Review Cambridge, 19(2), 316- 322.

Nurlela dan Islahudin.2008.Pengaruh Corporate Social Responsibility terhadap Nilai Perusahaan dengan Presentase Kepemilikan Manajemen sebagai Variabel Moderating. Simposium Nasional Akuntansi XI.

Nguyen, Bich Thi, Hai Thi Thanh Tran, Oanh Huang Le, Phuoc Thi Nguyen, Thien Hiep Trinh and Viet Le. 2015. Association between Corporate Social Responsibility Disclosures and Firm Value - Empirical Evidence from Vietnam. International Journal of Accounting and Financial Reporting, 5(1), 212-228.

Rani, Widiyasari Eko Putri. 2013. Pengaruh Profitabilitas Terhadap Pengungkapan Corporate Social Responsibility (Studi Empiris Pada Perusahaan Pertambangan 
I Made Adi Mahendra dan I Gusti Putu Wirawati. Pengaruh...

Yang Terdaftar Di Bursa Efek Indonesia Pada Tahun 2010 - 2012. Jurnal Akuntansi Universitas Brawijaya, 2(2), 1-26.

Ratna, Ni Ketut Kusumayanti. 2016. Corporate Social Responsibility Sebagai Pemediasi Pengaruh Ukuran Perusahaan, Profitabilitas, Dan Leverage Pada Nilai Perusahaan. E-Jurnal Akuntansi Universitas Udayana, 15(1), 549- 583.

Rustiarini, N. 2010. Pengaruh Corporate Governance Pada Hubungan Corporate Social Responsibility dan Nilai Perusahaan. Simposium Nasional Akuntansi XIII. Purwokerto.

Servaes, Henri. and Tamayo Ane. 2013. The Impact of Corporate Social Responsibility on Firm Value: The Role of Customer Awarness. Management Science, 59(5), 1045-1061.

Silvia, Agustina. 2013. Pengaruh Profitabilitas dan Pengungkapan Corporate Social Responsibility Terhadap Nilai Perusahaan (Studi Empiris Perusahaan Manufaktur yang Terdaftar di BEI). Jurnal Akuntansi, 1(1), 1-23.

Tija, Olivia dan Lulu Setiawati. 2012. Effect of CSR Disclosure to Firm Value: Study For Banking Industry In Indonesia. World Journal of Social Sciences, 2(6), 169-178.

Uadiale, Olayinka Marte and Temitope Olamide Fagbemi. 2012. Corporate Social Responsibility and Financial Perfomance in Developing Economies: The Nigerian Experience. Journal of Economics and Sustainable Development, 3(4), 44-54.

Vintila, Georgeta dan Florinita Duca. 2013. A Study of the Relationship between Corporate Responsibility - Financial Performance - Firm Size. Revista Romana de Statistica Trim, 1(1), 62-67.

Waryanti, 2009. Pengaruh Karakteristik Perusahaan terhadap Pengungkapan Sosial pada Perusahaan Manufaktur di Bursa Efek Indonesia. Skripsi. Fakultas Ekonomi Universitas Diponegoro.

White, G. I., Sondhi, A. C., and Dov, F. 2003. The Analysis and Use of Financial Statements. New York: John Wiley and Sons, Inc. 